\section{ADVANCED INFECTION CONTROL FOR YOUR PRACTICE}

Advanced Hygenex infection control products used in hospitals and care homes are now available for dentists, schools, colleges, universities and beauty clinics.

Healthcare professionals around the globe already depend on the trusted Hygenex brand with its wide range of infection control solutions. They include:

- The UK's first $100 \%$ organic and fully biodegradable hygiene wipes that can be flushed, macerated or composted without harming the planet - Hygenex cleansing wipes pass all seven tests set by the European Disposables and Nonwovens Association (EDANA) and the International Nonwovens and Disposables Association (INDA)

- Hygenex Recoat Antimicrobial Coating System - a spray-on coating that protects surfaces for up to six months against bacteria and viruses, including SARS-CoV-2/COVID-19

- Hand sanitiser to protect users against COVID-19 and other infections

- Medical pulp products including BioCommode, a fully self-supporting medical bedpan that needs no plastic support ... so it can be fully macerated, improving infection control.

Now the Hygenex brand has been launched as a separate company in its own right, enabling a wider range of users to gain access to its infection control solutions. Dentists, schools, colleges, universities and beauty clinics will be among the first offered the new advanced products.

For more information, contact Hygenex Marketing Director Zoe Allen, 01202 731555, info@hygenex.co.uk, www. hygenex.co.uk.
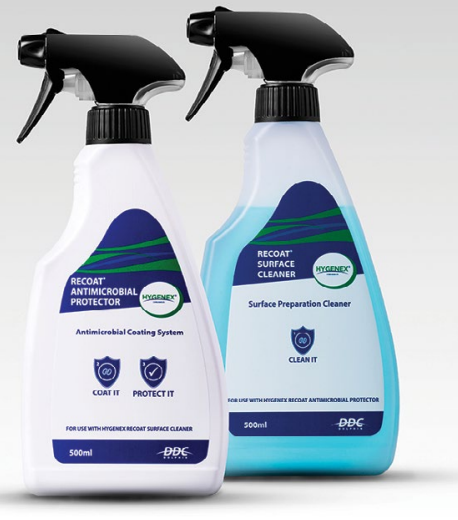

\section{BUFFING THE TEETH TO A BEAUTIFUL SMILE}

For a whiter and brighter smile in just 14 days, Arm \& Hammer WHITENING PRO PROTECT toothpaste can lighten the teeth by up to three shades in six weeks, when used twice a day.

\section{WHITENING PRO PROTECT will} clean and remove surface stains, naturally. Because Arm \& Hammer toothpastes

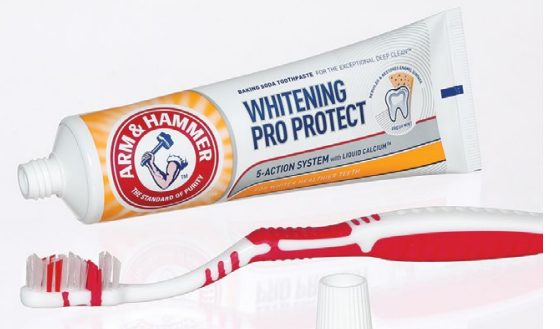

contain baking soda, they are low abrasive too, protecting the precious enamel.

Baking soda is a powerful ingredient, clinically recognised to enhance the plaque removal efficiency of toothbrushing compared to products which don't contain it. For added confidence, Arm \& Hammer toothpastes also contains Micropolisher Technology to gently buff the teeth to a beautiful shine.

Arm \& Hammer WHITENING PRO PROTECT toothpaste will get your patients' smiles noticed for all the right reasons.

For more information about the carefully formulated Arm \& Hammer toothpaste range, visit http://www. armandhammer.co.uk/ or email: ukenquiries@churchdwight.com.

Arm \& Hammer oral healthcare products are available at Boots, Superdrug, Sainsbury's, Tesco, Asda and Morrisons throughout the UK.

\section{IS YOUR INDEMNITY CREATED FOR YOU?}

So often dental hygienists and dental therapists have had to pay for indemnity that covers more than their scope of practice. These policies are often more expensive, leaving you wondering what you're paying for.

So, why not choose an indemnity policy specifically created for dental hygienists and dental therapists? Members of the British Society of Dental Hygiene and Therapy (BSDHT) can take out BSDHT Indemnity - a policy that has been created with these professions in mind.

This way, you can benefit from a tailored policy that protects your interests without the high price tag.

To join the BSDHT and find out more, contact the team today.

For more information about the BSDHT, visit www.bsdht.org.uk, call 01788 575050 or email enquiries@bsdht.org.uk.

\section{VISORS THAT} ACCOMMODATE YOUR LOUPES

Are you looking for a visor that enables you to wear your dental loupes comfortably?

Nuview offers two innovative solutions with the Nuview Headband Visor and the Nuview Loupe and Light Visor System. While the former is designed to be used with headband-mounted loupes and lights, the latter is ideal for framemounted loupe/light combinations.

Optimised for maximum user comfort and to comply with EN166:2001 requirements, these visors are positioned at a distance that your loupes and light can be used behind them. You can be confident they are also of a high optical quality to ensure supreme clarity.

For more information call Nuview on 01453 872266, email info@nuview-ltd. com, visit www.nuview.co.uk or 'like' Nuview on Facebook.
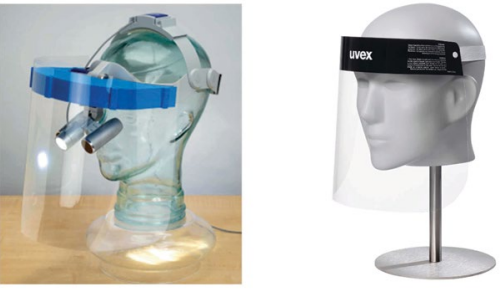